\title{
Heat and moisture migration in a geomembrane-GCL composite liner subjected to high temperatures and low vertical stresses ${ }^{\text {th }}$
}

\author{
A. Bouazza ${ }^{a, *}$, R.M. Singh ${ }^{\mathrm{a}, 1}$, R.K. Rowe ${ }^{\mathrm{b}, 2}$, F. Gassner ${ }^{\mathrm{c}, 3}$ \\ a Monash University, Department of Civil Engineering, 23 College Walk, Wellington Road, Clayton, Vic. 3800, Australia \\ ${ }^{\mathrm{b}}$ GeoEngineering Centre at Queen's-RMC, Queen's University, Ellis Hall, Kingston, Ontario, Canada K7L 3N6 \\ ' Golder Associates Pty. Ltd., Building 7, Botanicca Corporate Park, 570-588 Swan Street, Richmond, Vic. 3121, Australia
}

\section{A R T I C L E I N F O}

\section{Article history:}

Received 29 March 2014

Received in revised form 25 June 2014

Accepted 23 August 2014

Available online 12 September 2014

\section{Keywords:}

Ponds

Elevated temperatures

Geomembrane

Geosynthetic clay liner

Heat migration

Moisture migration

\begin{abstract}
A B S T R A C T
This paper presents the results of an experimental and numerical modelling of heat and moisture migration conducted on a composite liner comprised of a geomembrane (GMB) and a geosynthetic clay liner (GCL), over a compacted subgrade and subjected to prolonged elevated temperatures at low overburden stresses typical of brine storage ponds or solar evaporation ponds. Results are presented for a GMB sitting on a fully hydrated GCL. Heating the top of the composite liner caused a measurable increase in subgrade temperature to at least to $250 \mathrm{~mm}$ below the GCL. However, the presence of an air gap, simulating the presence of a wrinkle in the geomembrane, at the interface between the GMB and the GCL reduced the impact of the high temperatures on the subgrade temperature profile with depth. The change in temperature profile was accompanied by moisture migration from the GCL to the subgrade material. However no desiccation cracks were observed in the GCL and the bentonite was still in a gel form at the end of the time period investigated. Numerical modelling using finite element method (FEM) was performed to simulate the results obtained experimentally. It was found to predict accurately the temperature changes that have occurred in the subgrade material and moisture changes that occurred in both the GCL and subgrade materials.
\end{abstract}

(C) 2014 Published by Elsevier Ltd.

\section{Introduction}

Geosynthetic clay liners (GCLs) are thin (typically 5-10 mm) manufactured hydraulic barriers having a very low hydraulic conductivity to water $\left(k<10^{-10} \mathrm{~m} / \mathrm{s}\right)$ (Bouazza, 2002). Nowadays, they are commonly used in combination with geomembranes (GMB) in municipal solid waste (MSW) landfill liners (Bouazza et al., 2002; Rowe et al., 2004; Bouazza and Bowders, 2010). However, as their use has recently extended to mining and other industrial facilities they are exposed to a new variety of environmental conditions (Gates et al., 2009; Hornsey et al., 2010; Gates and Bouazza, 2010; Bouazza, 2010; Fourie et al., 2010; Shackelford et al., 2010; Mazzieri et al., 2013; Liu et al., 2013, 2014; Bouazza and Gates,

\footnotetext{
Dr. N. Touze-Foltz acted as Editor for the review of this paper.

* Corresponding author. Tel.: +61 39905 4956; fax: +61 399054944.

E-mail addresses: malek.bouazza@monash.edu (A. Bouazza), rao.singh@ monash.edu (R.M. Singh), kerry@civil.queensu.ca (R.K. Rowe), fgassner@golder. com.au (F. Gassner).

1 Tel.: +6139905 4981; fax: +6139905 4944 .

2 Tel.: +1 613533 3113; fax: +1 6135332128 .

3 Tel.: +613 8862 3584; fax: +6138862 3501 .
}

2014). In particular the effect of elevated temperatures has been identified as one of the factors governing the GCL's lining performance and longevity (Rowe, 2005; Bouazza, 2010; Bouazza et al., 2013; Abuel-Naga et al., 2013).

Unlike in municipal solid waste landfills where temperatures on liners can reach up to $60^{\circ} \mathrm{C}$ (Yesiller et al., 2005; Rowe, 2005, 2012; Koerner and Koerner, 2006; Bouazza et al., 2011) and then are expected to decay with time as biodegradation of wastes slows down, lining systems for mining and industrial infrastructures are exposed to prolonged elevated temperatures even higher than currently common in MSW landfills (Thiel and Smith, 2004; Bouazza, 2010; Hornsey et al., 2010). Recent research has indicated that liners in mining facilities (e.g., heap leach pads) can be continuously exposed to temperatures as high as $80{ }^{\circ} \mathrm{C}$ which are generated from the various ore extraction processes (Smith, 2008). Solar ponds liners can also experience high temperatures ranging from $30{ }^{\circ} \mathrm{C}$ at the surface to $90^{\circ} \mathrm{C}$ at the liner (Lu et al., 2001; Silva and Almanza, 2009). Similarly, warm liquid (generated from industrial processes) storage pond liners can reach temperatures up to $80{ }^{\circ} \mathrm{C}$ due to the dual effect of solar radiation and initial liquid temperatures, with long-term ( $>5$ years) temperatures ranging between $60^{\circ} \mathrm{C}$ and $80^{\circ} \mathrm{C}$ continuously acting on the lining system. 
Understandably, these high temperatures operating on the geosynthetic components of the lining systems have the potential to cause intense degradation of their physico-mechanical properties which in turn may impact on their service life under either low or high overburden stresses. In particular, the integrity of the hydraulic barrier (i.e., GCL in this case) may be compromised if it undergoes cracking due to desiccation caused by the presence of high thermal gradients. The presence of high temperatures in contact with liners can lead to thermally driven moisture flow and potentially to desiccation of the mineral component of the liner (i.e. compacted clay liners or geosynthetic clay liners). The coupled heat-moisture transfer process taking place in such cases (Mitchell, 1991; Rowe, 2005) causes a downward migration of water vapour from the mineral liner and the underlying subsoil to a cooler depth where it condenses, leading potentially to desiccation of the mineral liner, this is further exacerbated by the presence of the geomembrane which prevents moisture reaching the GCL from above (Southen and Rowe, 2005, 2011; Azad et al., 2011, 2012; Rowe and Verge, 2013; Hoor and Rowe, 2013).

This paper presents the results of a study aimed at quantifying heat and moisture migration in a composite liner comprising a geomembrane (GMB), with the presence of a wrinkle, and a fully hydrated GCL, overlying a compacted subgrade. Although the effect of wrinkles and their frequencies in landfills are well documented (Chappel et al., 2012a,b; Rowe et al., 2012a,b; Take et al., 2007), their occurrences and frequencies in brine storage ponds or solar evaporation ponds are yet to be quantified. The liner system in the current study is subjected to high temperatures and low overburden stresses typically encountered in lined liquid ponds. In addition to the experimental work, thermo-hydraulic numerical modelling of the composite liner system was conducted. The modelling was carried out using a finite element method (FEM) code referred to as COMPASS (Code for Modelling Partially Saturated Soils). This paper presents its main features and governing equations used for the numerical analysis as well as the main numerical model results.

\section{Experimental work}

\subsection{Materials}

The GCL used in the present investigation is composed of powdered sodium bentonite, needle-punched and thermally locked, between a nonwoven polypropylene geotextile cover layer and a woven polypropylene geotextile carrier (Table 1 ). The subgrade material was sourced from a site where a liquid storage pond was to be constructed. It had a liquid limit (LL) of $57 \%$, plastic limit $(\mathrm{PL})$ of $27 \%$ and specific gravity $\left(G_{s}\right)$ of 2.66 . It contained mostly fine grained soil particles with $82 \%$ particles finer than $60 \mu \mathrm{m}$. The maximum dry density and optimum moisture content from the standard Proctor compaction curve were $1520 \mathrm{~kg} / \mathrm{m}^{3}$ and $20 \%$, respectively. A standard HDPE geomembrane (GMB) having a nominal thickness of $2 \mathrm{~mm}$ was used in this study.

Table 1

Technical data sheet of the GCLs as provided by manufacturer.

\begin{tabular}{llll}
\hline Property & Test method & Unit & GCL \\
\hline Bentonite mass (@ 0\% moisture) content) & ASTM D5993 & $\mathrm{g} / \mathrm{m}^{2}$ & $4000^{\mathrm{a}}$ \\
Swell index & ASTM D5890 & $\mathrm{ml} / 2 \mathrm{~g}$ & $\geq 24$ \\
Fluid loss & ASTM D5891 & $\mathrm{ml}$ & $\leq 15$ \\
GCL total mass (@ 0\% moisture) content) & ASTM D5993 & $\mathrm{g} / \mathrm{m}^{2}$ & $4380^{\mathrm{a}}$ \\
Hydraulic conductivity & ASTM D5887 & $\mathrm{m} / \mathrm{s}$ & $2 \times 10^{-11}$ \\
\hline
\end{tabular}

$\mathrm{PP}=$ polypropylene geotextiles.

a MARV (minimum average roll value) is a mean value less 2 standard deviations.

\subsection{Apparatus}

A specially designed column was developed to simulate, as accurately as practical, the conditions occurring at the base of a liner subjected to low overburden pressures and elevated temperatures to allow an assessment of the potential for GCLs to desiccate under elevated thermal gradients.

The arrangement of the column allowed a temperature gradient to be applied across a composite liner and a subsoil of known initial conditions under controlled conditions. The apparatus was composed of three parts. The upper part consisted of a stainless steel water reservoir with the top cap fitted with a coil heater. This allowed for heating of the uppermost surface to simulate the heat present in a pond. Temperature changes were monitored by a thermocouple located in the reservoir. The heater and thermocouple were both connected to an automatic heating control unit which maintained the set temperature by thermostatically switching the heat on and off. This allowed the temperature of water to be raised in steps from room temperature to a target temperature. The top cap contained an inlet and an outlet to allow drainage and pressurisation of the water if needed.

The central part consisted of a polytetrafluoroethylene (PTFE) cylinder of $100 \mathrm{~mm}$ diameter and $400 \mathrm{~mm}$ height. PTFE has a very low thermal conductivity which limits radial heat losses during the experiment. This part provided access to both the upper and lower chambers and hosted the composite liner and the compacted subgrade material. Once the upper section was in place, it pinched the edges of both the geomembrane and GCL. Bentonite paste was then applied to the edge of the geomembrane to provide a seal at the interface. The pinching process allowed the creation of an air gap (i.e simulation of the presence of a wrinkle in the geomembrane) between the GMB and the GCL due mostly to the rigidity of the HDPE GMB. Heat application during the test increased the size of the gap due to the high thermal expansion of the HDPE GMB. The average size of the air gap was about $5 \mathrm{~mm}$. Staggered ports in the wall of the PTFE cylinder allowed installation of 3 relative humidity $(\mathrm{RH})$ sensors (capable also of monitoring temperature) and 4 thermocouples. All instrumentation was connected to a data-logger allowing continuous monitoring. The relative humidity sensors were installed in the upper portion of the central section while the thermocouples were installed in the bottom half of the central part.

The lower end of the subgrade material was maintained at constant temperature of $21 \pm 1^{\circ} \mathrm{C}$ through the lower chamber (3rd part of the column). This chamber was connected to a heating/ cooling unit system and had inlets to allow recirculation of water within the chamber at constant temperature. In this way the heat generated in the upper reservoir and migrating via the composite liner and subgrade material was absorbed by the circulating water resulting in a constant temperature applied at the bottom end of the subgrade. A thermocouple located at the interface between the lower chamber and the compacted subgrade gave a continuous reading of the temperature. The bottom boundary was sealed (no flow boundary) to prevent any moisture changes. Once the column was assembled, the upper chamber was tightly screwed with tie rods to the lower chamber and left for 10 days to reach equilibrium under room temperature prior to commencing the test.

The procedure followed to raise the temperature in the upper chamber to the target temperature $\left(70^{\circ} \mathrm{C}\right)$ consisted of increasing the temperature in increments from room temperature $\left(21 \pm 1{ }^{\circ} \mathrm{C}\right)$ to $30{ }^{\circ} \mathrm{C}$ for $24 \mathrm{~h}$, then to $50{ }^{\circ} \mathrm{C}$ for another $24 \mathrm{~h}$. It was kept at this temperature for 5 days before it was raised to $65{ }^{\circ} \mathrm{C}$, and then 10 days later the temperature was raised to the target temperature of $70^{\circ} \mathrm{C}$. The temperature conditioning process therefore took in total 16 days to complete. The upper chamber was kept at the target 
temperature for 50 days. This process mimicked the site operation where the liner is first subjected to ambient temperature in Queensland, Australia before it came into contact with the brines $\left(50{ }^{\circ} \mathrm{C}\right)$ and then accounted for solar radiation effect $\left(60-70{ }^{\circ} \mathrm{C}\right)$.

\subsection{Materials preparation}

The main stages followed in the materials preparation prior to the column test are presented in the following:

A GCL specimen was cut from a larger GCL sample, using a sharp utility knife, to a diameter of $120 \mathrm{~mm}$. The hydration process followed the procedure reported in Bouazza and Vangpaisal (2003). In summary, it consisted of immersing the specimen in de-ionised water in an immersion tank for 1 week under a $2 \mathrm{kPa}$ axial pressure. Once this process was completed, the GCL was stored in two resealable plastic bags, under a $2 \mathrm{kPa}$ surcharge, for another week to avoid water evaporation during the curing period and allow homogenisation of the moisture content within the GCL. The dry initial thickness $\left(H_{G C L d}\right)$ and mass of GCL were measured prior to immersion. This process was repeated after the curing process was completed to obtain the initial hydrated thickness and wet mass (i.e., prior to placement in the column). Calibration tests indicated that the cured moisture content achieved following this process was $300 \%$ with thickness reaching $14 \mathrm{~mm}$. The subgrade material (300 mm thickness) was compacted inside the column to a dry density of $1380 \mathrm{~kg} / \mathrm{m}^{3}$ and a moisture content of $18 \%\left(S_{r}=52 \%\right.$, $k_{\text {sat }}=1 \times 10^{-8} \mathrm{~m} / \mathrm{s}$ ) to mimic average subgrade preparation. Once this process was completed the fully hydrated GCL specimen was placed on top of the subgrade followed by the placement of the geomembrane specimen.

\section{Numerical modelling}

The finite element code (COMPASS) used in the present investigation was developed at the University of Cardiff, U.K. It is based on a mechanistic approach; its development is detailed extensively in various publications (Thomas and King, 1991; Thomas and He, 1995; Thomas and Sansom, 1995; Thomas et al., 1996; Thomas and Li, 1997; Thomas and Cleall, 1999; Wang, 2000; Seetharam, 2003). It is capable of numerically simulating thermo-hydraulicmechanical and chemical (THM-C) processes in unsaturated porous medium. This study used only the thermo-hydraulic (TH) capability of the code. The governing equations are expressed in terms of three primary variables for the TH modelling: pore water pressure $\left(u_{l}\right)$, pore air pressure $\left(u_{a}\right)$ and temperature $(T)$. A numerical solution of the coupled equations is achieved via utilisation of the finite element method for spatial discretisation and the finite difference method for temporal discretisation, full details can be found in Thomas and King (1991), Thomas and He (1995) and Thomas and Sansom (1995).

\subsection{Moisture transfer}

Moisture transfer in unsaturated soil may be described as comprising the flow of liquid water and the flow of water vapour. Based on the law of conservation of mass, the combined liquid and vapour flow can be mathematically expressed as (Thomas and He, 1997):

$\rho_{l} \frac{\partial\left(n S_{l}\right)}{\partial t}+\frac{\partial\left(\rho_{v} n S_{a}\right)}{\partial t}=-\rho_{l} \nabla \cdot v_{l}-\rho_{l} \nabla \cdot v_{v}-\nabla \cdot\left(\rho_{v} v_{a}\right)$

where $n$ is the porosity, $S_{l}$ and $S_{a}$ are the degree of saturation of pore water and pore air respectively. The terms $v_{l}, v_{v}$ and $v_{a}$ represent the velocity of liquid, vapour and air respectively. The terms $\rho_{l}$ and $\rho_{v}$ represent density of liquid and vapour respectively, $\nabla$ is the gradient operator and $t$ represents time.

The flow of liquid water through unsaturated soil can be described via Darcy's law:

$v_{l}=-\frac{k_{l}}{\mu_{l}}\left[\nabla\left(\frac{u_{l}}{\gamma_{l}}\right)+\nabla z\right]=-K_{l}\left[\nabla\left(\frac{u_{l}}{\gamma_{l}}\right)+\nabla z\right]$

where $k_{l}$ is the intrinsic permeability, $\mu_{l}$ is the absolute viscosity of pore liquid, $K_{l}$ is the unsaturated hydraulic conductivity which is a function of both moisture content and temperature, $\gamma_{l}$ is the unit weight of liquid and $z$ is the elevation.

Vapour transfer occurs as a result of two main mechanisms, namely; diffusive and pressure flows. The diffusive flow contribution to vapour transport may be dealt with by a flow law proposed by Philip and de Vries (1957), Ewen and Thomas (1989) and extended by Cleall et al. (2011, 2013) as:

$$
\begin{aligned}
v_{v}= & \frac{D_{a t m s} v_{v} n}{\rho_{l}}\left(\rho_{o} \frac{\partial h}{\partial s}\right) \nabla u_{l}-\frac{D_{a t m s} v_{v} n}{\rho_{l}} \frac{(\nabla T)_{a}}{\nabla T}\left(h \frac{\partial \rho_{o}}{\partial T}+\rho_{o} \frac{\partial h}{\partial T}\right) \nabla T \\
& -\frac{D_{a t m s} v_{v} n}{\rho_{l}}\left(\rho_{o} \frac{\partial h}{\partial s}\right) \nabla u_{a}
\end{aligned}
$$

where $D_{a t m s}$ is the molecular diffusivity of vapour through air, $v_{v}$ is a mass flow factor, $(\nabla T)_{a} / \nabla T$ is the microscopic pore temperature gradient factor, $h$ is the relative humidity, $s$ is the suction and $\rho_{0}$ is the saturated vapour density.

\subsection{Dry air transfer}

In an unsaturated geomaterial, dry air can be considered to consist of bulk air and dissolved air. Bulk air transfer is driven by a gradient of air pressure and is determined by the use of Darcy's law. Dissolved air is taken to be transferred advectively within the pore liquid and Henry's law is used to define the proportion of dry air contained in the pore liquid. Applying the law of conservation of mass the temporal derivative of the dry air content is equal to the spatial derivative of the dry air flux. Mathematically this can be expressed as:

$\frac{\partial\left(\theta_{a}+H_{s} \theta_{l}\right) \rho_{d a} \partial V}{\partial t}=-\partial V \cdot \nabla \cdot\left[\rho_{d a}\left(v_{a}+H_{s} v_{l}\right)\right]$

where $\theta_{a}$ is the volumetric air content, $\theta_{l}$ is the volumetric liquid water content, $\partial V$ is the incremental volume, $H_{s}$ is Henry's volumetric coefficient of solubility and $\rho_{d a}$ is the density of dry air.

\subsection{Heat transfer}

There are three principal methods of heat transfer; conduction, convection, and radiation. The effect of latent heat of vaporisation is also included; the law of conservation of energy for heat flow dictates that the temporal derivative of the heat content, $H_{c}$ is equal to the spatial derivative of the heat flux, $Q$. This may be expressed as:

$$
\begin{aligned}
& \frac{\partial\left(H_{c} \partial V\right)}{\partial t}=-\nabla Q(\partial V) \\
& Q=-K_{T} \nabla T+\left(v_{v} \rho_{v}+v_{a} \rho_{v}\right) L+\left(C_{p l} v_{l} \rho_{l}+C_{p v} v_{v} \rho_{l}+C_{p v} v_{a} \rho_{v}\right. \\
& \left.+C_{p d a} v_{a} \rho_{d a}\right)\left(T-T_{r}\right)
\end{aligned}
$$


where $K_{T}$ is the thermal conductivity of unsaturated soil, $C_{p l}, C_{p v}$, and $C_{p d a}$ are the specific heat capacities of liquid, vapour, and dry air, $L$ is the latent heat of vaporisation, $T_{r}$ is the reference temperature.

\subsection{Application to the column test}

Details of the analysis undertaken including definition of domain and its discretisation, initial and boundary conditions and material parameters are presented in the following sections.

\subsubsection{Geometry and discretisation}

An axisymmetric domain geometry used in the numerical study is presented in Fig. 1. The geometry adopted for the numerical modelling corresponds to the specimen size used in the laboratory experiment. Pseudo 1D axisymmetric numerical analysis was performed to simulate the temperature distribution obtained from the column test. The whole domain was discretised into a uniform mesh of 321, 4 noded iso-parametric, elements. A time step of $100 \mathrm{~s}$ was found to yield converged results.

\subsubsection{Initial conditions}

Initial conditions adopted corresponded to the initial conditions used for the laboratory experiment. Initial temperature for the whole domain was considered to be $20^{\circ} \mathrm{C}$ equal to room temperature. Initial degree of saturation of the GCL was taken as $100 \%$ representative of the fact that the GCL was fully hydrated. The degree of saturation of the clayish subgrade was $52 \%$ and corresponded to the experimental conditions. Initial suction (negative pore water pressure) of the GCL and subgrade material corresponded to their initial degree of saturation. The initial suction values were determined from water retention curves (WRCs) obtained for both materials. The initial conditions employed for the numerical analysis are shown in Fig. 1.

\subsubsection{Boundary conditions}

Boundary conditions used during the numerical analysis were similar to the ones used in the column test and are presented in Fig. 1. A fixed temperature was set at the top boundary (i.e. top surface of the GMB) and was increased in steps from $20^{\circ} \mathrm{C}$ to $70^{\circ} \mathrm{C}$ in a similar fashion to the laboratory experiment. A fixed temperature of $21{ }^{\circ} \mathrm{C}$ was adopted for the bottom boundary (lower chamber). No radial heat losses were assumed from the side vertical boundary.

\subsubsection{Material parameters}

Most of the material parameters used in the numerical analysis were determined experimentally (see Table 2 and following sections for further details). A unit tortuosity factor was adopted due to the lack of available data for the tested GCL and subgrade material. The tortuosity factor affects the vapour transfer by controlling the pore space available for vapour movement and values lower than 1 will delay the drying process slightly.

3.4.4.1. Thermal conductivity. Heat flow through soils occurs entirely by conduction, with radiation unimportant and convection important, only if there is high flow rate of water or air (Mitchell, 1993). Johansen (1975) considered thermal radiation across soil air spaces and concluded that it was only significant for very coarse material at low moisture contents. Heat transfer was also found to occur due to chemical concentration gradients. This effect is commonly referred to as the Dufour effect. Mitchell (1993) stated that the Dufour effect has not been found to be of significance in soils. The fundamental equation for heat conduction as derived by Fourier (1822) is as follows:
$Q=-K_{T} \nabla T$

where $Q$ is the heat flux per unit area whereas in Darcy's equation it was the mass flux, $K_{T}$ is the thermal conductivity, $\nabla T$ is the temperature gradient.

The coefficient of thermal conductivity of unsaturated geomaterials has been found to be a function of degree of liquid water saturation $\left(S_{l}\right)$ typically exhibiting an increase with increasing water content, i.e.:

$K_{T}=f\left(S_{l}\right)$

Thermal conductivities of the GMB, GCL and subgrade material were measured in the laboratory using a divided bar method and a needle probe method, respectively (Singh and Bouazza, 2013; Barry-Macaulay et al., 2013). Readers are referred to these two references for further details on test set ups and measurement procedures.

Fig. 2 presents the variation of thermal conductivity against degree of saturation for both GCL and subgrade material. The degree of saturation of the GCL is the apparent degree of saturation as defined by Anderson et al. (2012). These figures show that thermal conductivity varied with water content and was observed to increase linearly with an increase in water content. Similar observations were reported for different type of materials (Abu-Hamdeh and Reeder, 2000; Abuel-Naga et al., 2008, 2009, Barry-Macaulay et al., 2013). The GMB was found to have a thermal conductivity of $0.14 \mathrm{~W} / \mathrm{m} \mathrm{K}$. Thermal conductivity of air was taken to be $0.03 \mathrm{~W} /$ $\mathrm{m} \mathrm{K}$ as reported in literature.

3.4.4.2. Water retention curve (WRC) and unsaturated hydraulic conductivity. The water retention curve (WRC) provides the relationship between suction and water content (volumetric or gravimetric). The suction results obtained experimentally usually comprise only a small portion of the WRC. Therefore, curve fitting is used to predict the retention curve of both the GCL and the subgrade material (Fig. 3). In the present study, van Genuchten (1980) numerical curve fitting equation (eq. (9)) was used to establish the water retention curves of both materials.

$\frac{\theta_{l}-\theta_{l r}}{\theta_{l s}-\theta_{l r}}=\left[\frac{1}{1+(\alpha s)^{n}}\right]\left(1-\frac{1}{n}\right)$

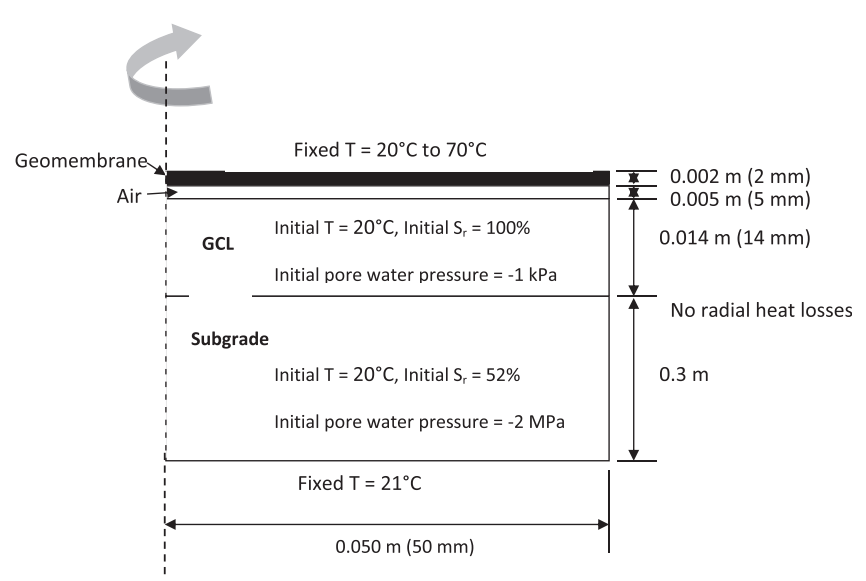

Fig. 1. 1D axisymmetric geometry used in numerical modelling with initial and boundary conditions. 
Table 2

Material parameters used for numerical modelling (absolute reference temperature $21^{\circ} \mathrm{C}$ ).

\begin{tabular}{|c|c|c|c|c|}
\hline Parameters & GCL & Subgrade & GM & Air \\
\hline $\begin{array}{l}\text { Hydraulicparameters } \\
\text { Saturated hydraulic conductivity, } k_{\text {sat }}(\mathrm{m} / \mathrm{s}) \\
\text { Unsaturated hydraulic conductivity, } k_{l}(\mathrm{~m} / \mathrm{s}) \\
\text { van Genuchten (1980) fitting parameters }\end{array}$ & $\begin{array}{l}1.0 \times 10^{-11 a} \\
k_{l}=\left(S_{r}\right)^{\delta} k_{\text {sat }} \text { and } \delta=3 \\
\alpha=0.6 \\
n=1.3 \\
m=0.23 \\
\theta_{l r}=0.0001 \\
\theta_{l s}=0.387\end{array}$ & $\begin{array}{l}1.0 \times 10^{-8 \mathrm{a}} \\
k_{l}=\left(S_{r}\right)^{\delta} k_{\text {sat }} \text { and } \delta=3 \\
\alpha=0.009 \\
n=1.95 \\
m=0.487 \\
\theta_{l r}=0.0001 \\
\theta_{l s}=0.3\end{array}$ & $1.0 \times 10^{-15 b}$ & $1.0 \times 10^{-15 b}$ \\
\hline $\begin{array}{l}\text { Thermal soil parameters } \\
\text { Thermal conductivity, } \lambda(\mathrm{W} / \mathrm{m} \mathrm{K}) \\
\text { Specific heat capacity, } C_{p s}(\mathrm{~J} / \mathrm{kg} \mathrm{K})\end{array}$ & $\begin{array}{l}\lambda=f\left(S_{r}\right)^{\mathrm{a}} \\
800\end{array}$ & $\begin{array}{l}\lambda=f\left(S_{r}\right)^{\mathrm{a}} \\
800\end{array}$ & $\begin{array}{l}0.14^{a} \\
800\end{array}$ & $\begin{array}{l}0.03^{c} \\
1000\end{array}$ \\
\hline $\begin{array}{l}\text { Soil liquid moisture } \\
\text { Density, } \rho_{l}\left(\mathrm{~kg} / \mathrm{m}^{3}\right) \\
\text { Thermal conductivity, } \lambda_{l}(\mathrm{~W} / \mathrm{m} \mathrm{K}) \\
\text { Latent heat of vaporisation, } L(\mathrm{~J} / \mathrm{kg})\end{array}$ & $\begin{array}{l}1000 \\
0.6 \\
2.4 \times 10^{6}\end{array}$ & $\begin{array}{l}1000 \\
0.6 \\
2.4 \times 10^{6}\end{array}$ & $\begin{array}{l}1000 \\
0.6 \\
2.4 \times 10^{6}\end{array}$ & $\begin{array}{l}1000 \\
0.6 \\
2.4 \times 10^{6}\end{array}$ \\
\hline $\begin{array}{l}\text { Soil vapour moisture } \\
\text { Specific heat capacity, } C_{p v}(\mathrm{~J} / \mathrm{kg} \mathrm{K}) \\
\text { Specific gas constant, } R_{v}(\mathrm{~J} / \mathrm{kg} \mathrm{K})\end{array}$ & $\begin{array}{l}1870 \\
461.5\end{array}$ & $\begin{array}{l}1870 \\
461.5\end{array}$ & $\begin{array}{l}1870 \\
461.5\end{array}$ & $\begin{array}{l}1870 \\
461.5\end{array}$ \\
\hline
\end{tabular}

${ }^{a}$ Measured at the Monash laboratory.

b Values selected to indicate that no liquid flow occurred between GM and GCL.

c Standard values.

where $\theta_{l}$ is the volumetric liquid water content, $\theta_{l r}$ is the residual volumetric liquid water content, $\theta_{l s}$ is the saturated volumetric liquid water content, $s$ is the matric suction and $\alpha, n$ are constant fitting parameters.

The van Genuchten (1980) model was fitted to the experimental values reported by Abuel-Naga and Bouazza (2010)and Beddoe et al. (2011) for a similar type of GCLs. The suction of the subgrade was measured experimentally using a chilled mirror hygrometer technique (Ali et al., 2014). Similarly van Genuchten (1980) model was fitted to the subgrade experimental data. Fitting parameters for both cases are tabulated in Table 2.

Melhuish (2004) reported that the unsaturated hydraulic conductivity for a compacted bentonite, $K_{l}$, is a function of the void ratio, the degree of saturation and the temperature. In this approach $K_{l}$ was associated with the hydraulic conductivity of

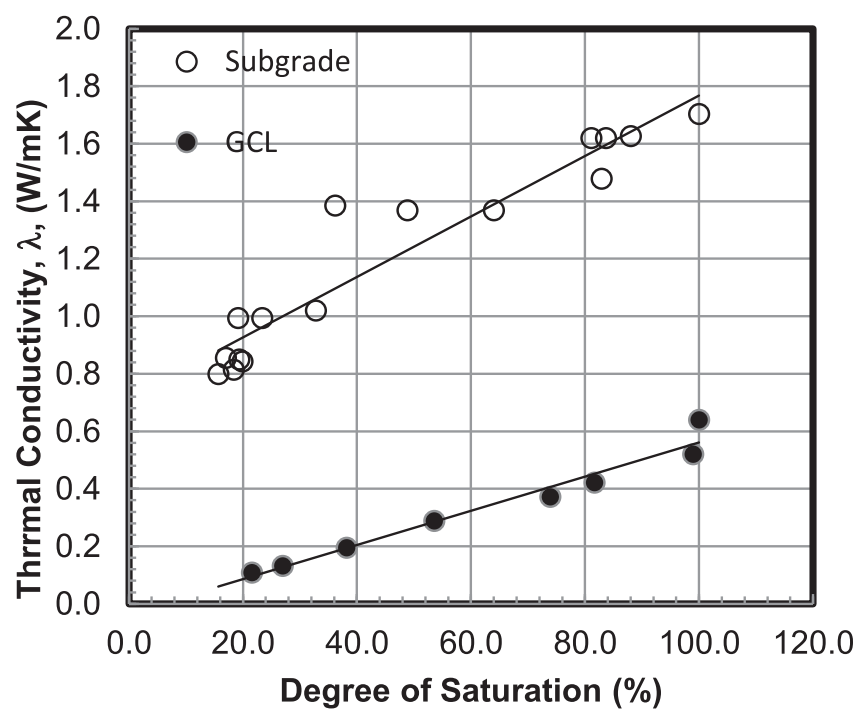

Fig. 2. Thermal conductivity variation against degree of saturation for GCL and subgrade materials. saturated clay, $k_{\text {sat }}$, and the degree of saturation, $S_{l}$, by the following relationship:

$K_{l}=\left(S_{l}\right)^{\delta} k_{\text {sat }}$

where $\delta$ is a parameter varying between 3 and 10. A value of 3 was used in the present investigation based on the calibration and validation performed by Börgesson and Hernelind (1998) on bentonitic clays. The saturated hydraulic conductivity of the GCL and subgrade material was obtained using a flexible wall permeameter as per ASTM D5887-09 and ASTM D5084-10, respectively.

\section{Results and discussion}

\subsection{Experimental work}

Fig. 4 shows the temperature variation across the subgrade material. The effect of increased temperature, above the composite liner, on the subgrade material was very noticeable. The temperature of the subgrade increased to about $42{ }^{\circ} \mathrm{C}$ at $20 \mathrm{~mm}$ below the GCL and to $37{ }^{\circ} \mathrm{C}$ and $32{ }^{\circ} \mathrm{C}$ at $50 \mathrm{~mm}$ and $100 \mathrm{~mm}$, respectively, below the GCL, at the target temperature $\left(70^{\circ} \mathrm{C}\right.$ above the GM). Smaller increases occurred toward the far end of the column where temperatures varied between $29{ }^{\circ} \mathrm{C}$ at $200 \mathrm{~mm}$ and $26{ }^{\circ} \mathrm{C}$ at $250 \mathrm{~mm}$ from the top. The results reported herein indicate that a continuous elevated temperature of $70^{\circ} \mathrm{C}$ acting on the liner could affect the temperature profile in the subgrade at least to $200 \mathrm{~mm}$ below the GCL under the test temperature boundary condition set at the base of the cell.

However, from Fig. 5, the major changes in the temperature profile were observed to occur at depth $\leq 100 \mathrm{~mm}$, with the largest change taking place at the interface between the subgrade material and the GCL where a drop of about $30{ }^{\circ} \mathrm{C}$ was recorded. This indicates that the presence of an air gap (representative of a wrinkle with no defects) between the geomembrane and the GCL has worked as an insulator and shielded the subgrade from exposure to higher temperatures. Beyond this point, the subgrade temperature decreased steadily and remained relatively constant at $22{ }^{\circ} \mathrm{C}$ 

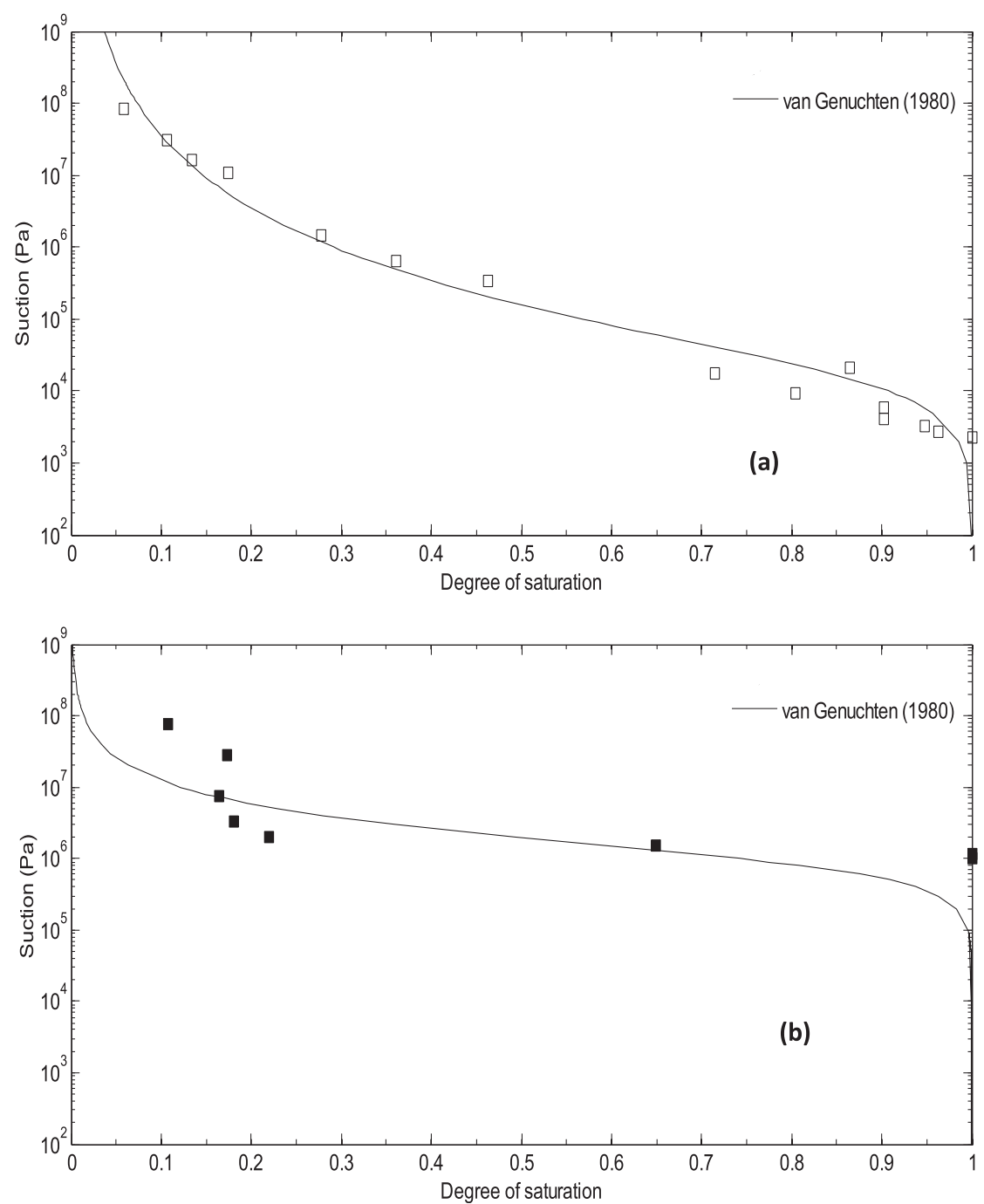

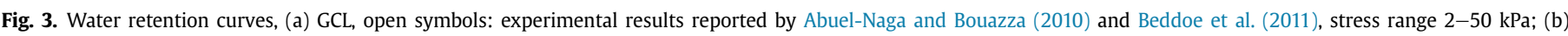
subgrade, closed symbols: experimental results from present study.

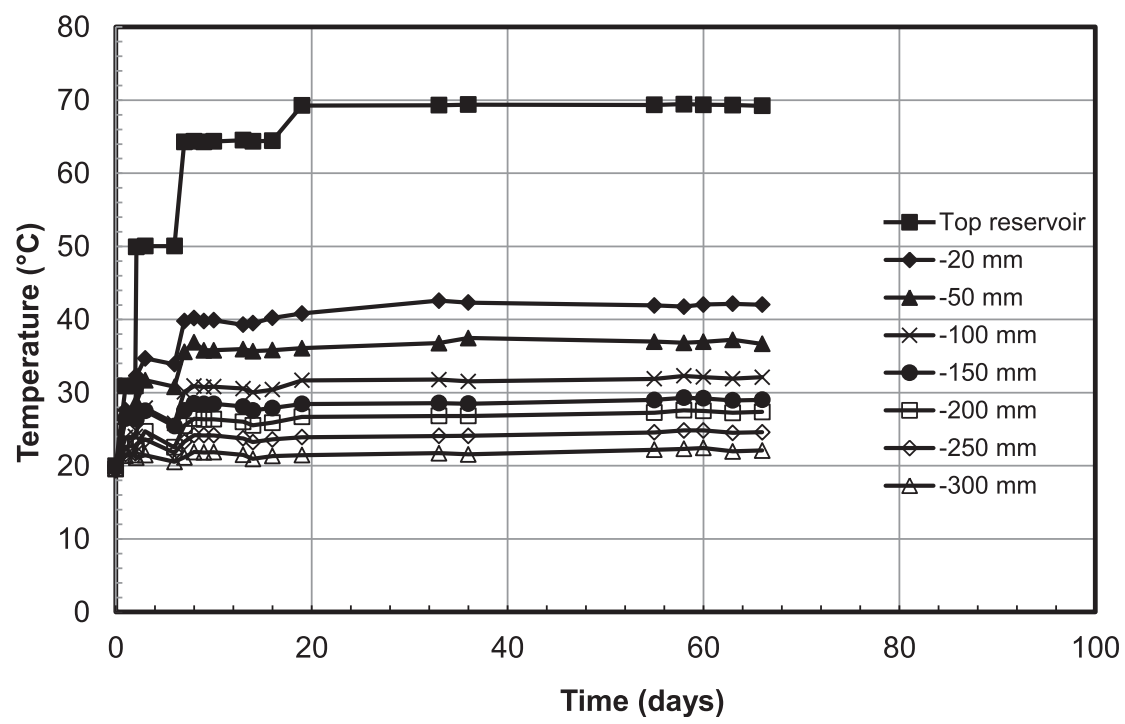

Fig. 4. Variation of temperature with time in the subgrade material at different depths. 
Temperature $\left({ }^{\circ} \mathrm{C}\right)$

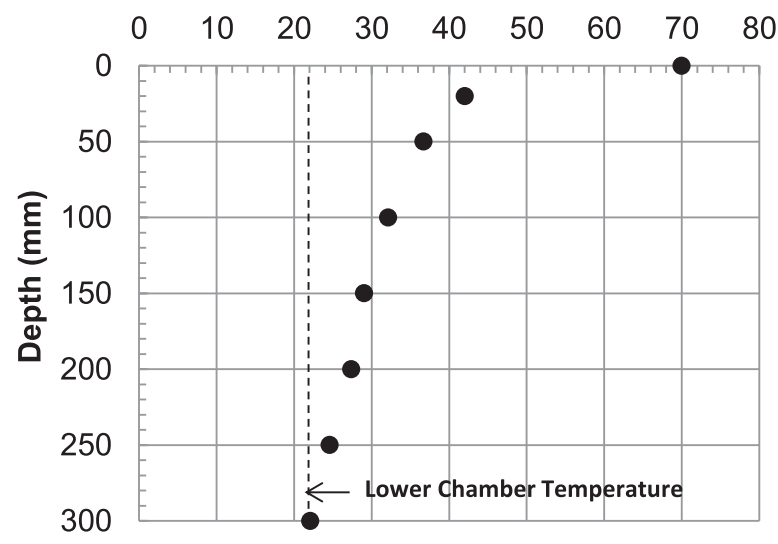

Fig. 5. Variation of temperature in the subgrade material at equilibrium.

beyond $250 \mathrm{~mm}$ depth which is close to the constant temperature $\left(21 \pm 1^{\circ} \mathrm{C}\right)$ of the lower chamber.

Fig. 6 presents the relative humidity $(\mathrm{RH})$ results measured at depths of $20 \mathrm{~mm}, 50 \mathrm{~mm}$ and $100 \mathrm{~mm}$, respectively, from the interface of the subgrade and the GCL. The initial RH was 95\% at all the locations in the subgrade. The relative humidity increased to $100 \%$ within few days of the temperature increase in the upper chamber due to the migration of moisture from the fully hydrated GCL caused by continuous heating. The relative $\mathrm{RH}$ reached $99 \%$ at $20 \mathrm{~mm}$ depth within the $1 \mathrm{st}$ day of heating at only $30^{\circ} \mathrm{C}$, and as the wetting front moved across the subgrade the other two sensors reached $100 \%$ within 2 days of heating. No change in the relative humidity occurred for the remainder of the experiment indicating that moisture was still migrating from the GCL. The test was stopped after 60 days of heating; therefore it is not known how long the test would have been required to continue to see a drop in the relative humidity of the subgrade, if at all.

Specimens of the GCL and subgrade material from the top $20 \mathrm{~mm}$ were retrieved from the column at the completion of the test for moisture content measurements; no attempts were made to profile the rest of the column. The results indicated that the GCL water content dropped from $300 \%$ (apparent degree of saturation of $100 \%$ ) to $60 \%$ (apparent degree of saturation of $21.3 \%$ ) due to the continuous heating. In terms of apparent saturation this represents a drop from $100 \%$ to $21.3 \%$, apparent saturation is defined as the moisture content $(w)$ of a GCL at a given time divided by the maximum hydration moisture content $\left(w_{\text {ref }}\right)$ for that GCL (in the

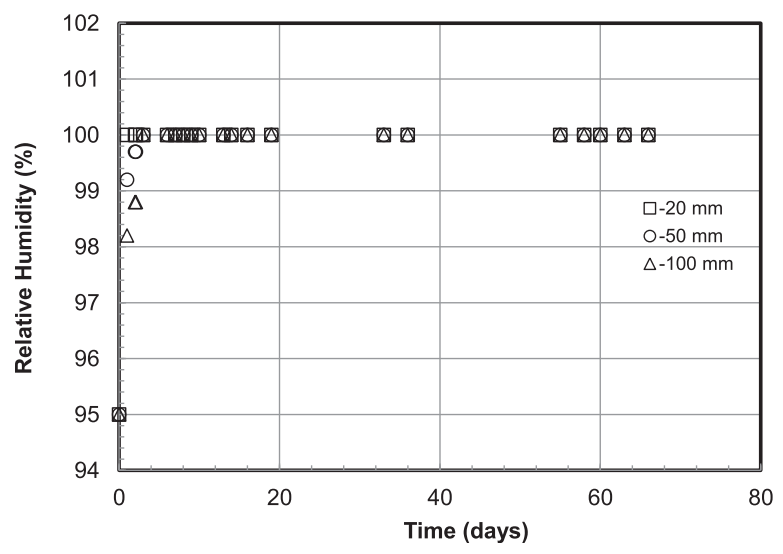

Fig. 6. Relative humidity variation with time in subgrade material.

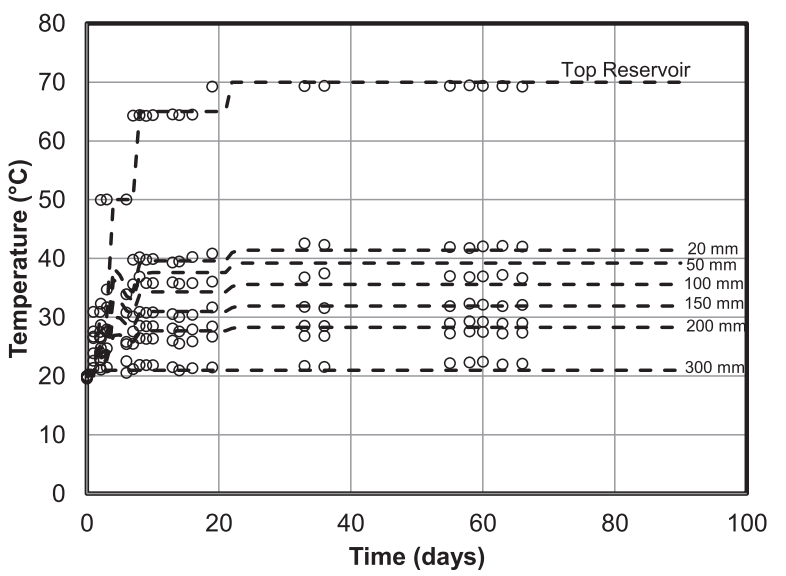

Fig. 7. Numerical and experimental temperature variations with time in the subgrade material at different depths (open symbols: experimental results).

present case the maximum hydration moisture content, achieved after immersion) (Rayhani et al., 2011; Anderson et al., 2012). While this is a significant drop, no desiccation cracks were observed in the GCL and the bentonite was still in a gel form for the time period investigated. This is likely due to the controlled heating conditions imposed and also probably due to the fact that the test was not run long enough. The subgrade material (top $20 \mathrm{~mm}$ ) water content was found to have increased from $18 \%$ (i.e., $S_{r}=52 \%$ ) to $25 \%$ $\left(S_{r}=64 \%\right)$, indicating that moisture migration from the GCL occurred while the composite liner was subjected to continuous heating for close to 60 days. These observations confirmed the relative humidity results reported in Fig. 3.

\subsection{Numerical modelling}

Temperature results obtained numerically are presented in Fig. 7. It can be observed that temperature reaches steady state at all locations in the GCL and in the subgrade and its distribution is quite uniform. There is a temperature drop at the beginning at almost all the locations. This is due to the change in thermal conductivity as moisture moves from the top hot end to the bottom colder end. As indicated earlier, thermal conductivity was found to vary linearly with increase in water content and COMPASS takes this aspect into account. The numerical results were found to match the experimental results quite well. Fig. 8 shows the comparison between the

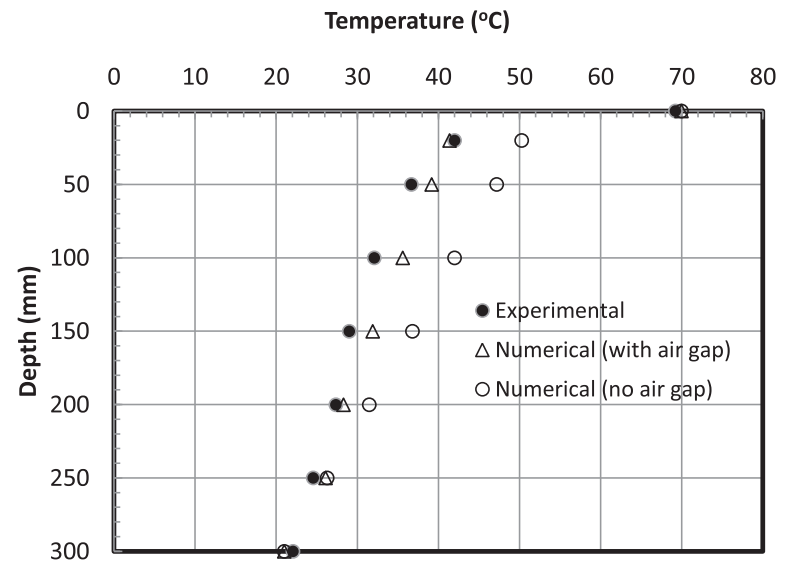

Fig. 8. Numerical and experimental temperature profiles with depth at equilibrium of the subgrade material. 


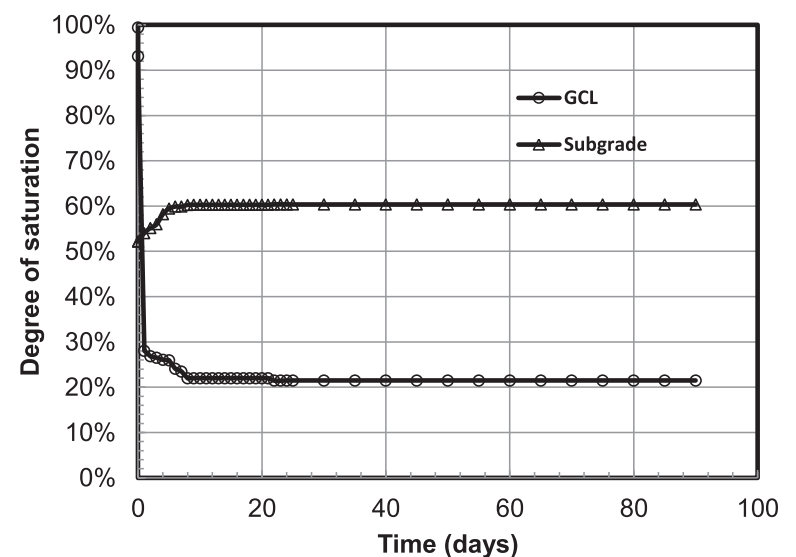

Fig. 9. Numerical prediction of degree of saturation variation in GCL and subgrade materials.

temperature profiles with depth obtained numerically and experimentally on the subgrade material. It also includes the results obtained for the case where no gap was present between the GMB and the GCL for comparative purposes. The above results indicate the ability of COMPASS to predict accurately the temperature changes that have occurred in the subgrade material. More importantly it confirms the shielding effect that the presence of an air gap has on the subgrade material.

Fig. 9 presents the variation of the degree of saturation versus time inside the GCL and in the subgrade material at the interface with the GCL. Saturation is shown to decrease in the GCL very rapidly as the presence of heat drove moisture away from the GCL into the subgrade material until a steady state condition was reached (i.e., no further moisture migration was observed). The degree of saturation for the GCL dropped from $100 \%$ to $22 \%$ which corresponds to the experimental observation where the GCL apparent saturation at steady state was found to reach $21 \%$. The moisture migration from the GCL resulted in the increase of the degree of saturation of the subgrade material (at the interface with the GCL) from 52\% (initial state) to $60 \%$ at steady state which compares well with the value of $64 \%$ obtained experimentally. The numerical model was able to predict the changes of the degree of saturation in both GCL and subgrade material reasonably well.

It is to be noted that the numerical model used in this study considered the composite liner and subgrade as non-deformable rigid materials which is a reasonable assumption in the present context as the experiment was conducted under a low stress of about $1 \mathrm{kPa}$. It is possible that the GCL may change thickness due to the thermal gradient application. However, Abuel-Naga and Bouazza (2013) reported in an earlier work that under low vertical stresses very low values of volumetric contractions were observed on a fully saturated GCL, similar to the one used in this study, when subjected to temperatures ranging between $30^{\circ} \mathrm{C}$ to $60{ }^{\circ} \mathrm{C}$. Further studies need to be carried out to validate the existing model for a deformable medium subjected to higher vertical stresses. Furthermore, the GCL water retention properties need to be re-evaluated to account for thermo-mechanical coupling effects. Such work is already underway (El-Zein et al., in press).

\section{Conclusions}

Continuous application of high temperatures on a composite liner comprised of a geomembrane and GCL resting on a subgrade material indicated that the subgrade temperature profile was affected at least to $250 \mathrm{~mm}$ below the GCL. However, the presence of an air gap simulating the presence of a wrinkle in the geomembrane at the interface between the GMB and the GCL indicates that it shielded the subgrade from the high temperatures present on top of the geomembrane and reduced their impact on the temperature profile with depth. It was also observed that the change in temperature profile was accompanied by moisture migration from the GCL to the subgrade material. However no desiccation cracks were observed in the GCL and the bentonite was still in a gel form for the time period investigated. The finite element code COMPASS was found to predict accurately the temperature and moisture changes that have occurred in a composite lining system subjected to a low vertical stress and high temperatures, and offers the possibility of further investigation in THM modelling of lining systems.

\section{Acknowledgement}

The authors are grateful to Prof Hywel Thomas, GRC, Cardiff University, for providing access to the finite element numerical code COMPASS used in this study.

\section{References}

ASTM D5887, 2009. Standard Test Methods for Measurement of Index Flux through Saturated Geosynthetic Clay Liner Specimens Using a Flexible Wall Permeameter. ASTM International, West Conshohocken, PA.

ASTM D5084, 2010. Standard Test Methods for Measurement of Hydraulic Conductivity of Saturated Porous Materials Using a Flexible Wall Permeameter. ASTM International, West Conshohocken, PA.

Abuel-Naga, H., Bouazza, A., 2010. A novel laboratory technique to determine the water retention curve of geosynthetic clay liners. Geosynth. Int. 17 (5), 313-322.

Abuel-Naga, H.M., Bergado, D.T., Bouazza, A., 2008. Thermal conductivity of soft Bangkok clay: experimental results and modelling. Int. J. Geomech. 8 (2), 114-122.

Abuel-Naga, H.M., Bergado, D.T., Bouazza, A., 2009. Laboratory and field therma conductivity of a saturated clay. Eng. Geol. 105 (3-4), 211-219.

Abuel-Naga, H.M., Bouazza, A., 2013. Thermo-mechanical behaviour of geosynthetic clay liners. J. Geotech. Geoenviron. Eng. 139 (4), 539-547.

Abuel-Naga, H.M., Bouazza, A., Gates, W.P., 2013. Impact of bentonite form on the thermal evolution of the hydraulic conductivity of geosynthetic clay liners. Geotech. Lett. 3, 26-30.

Abu-Hamdeh, N.H., Reeder, R.C., 2000. Soil thermal conductivity: effects of density, moisture, salt concentration, and organic matter. Soil Sci. Soc. Am. J. 64 1285-1290.

Ali, M.A., Singh, R.M., Bouazza, A., Gates, W.P., Rowe, R.K., 2014. Variation of total suction of a clayey soil with temperature. In: Proceeding 6th Internationa Conference on Unsaturated Soils, vol. 1, pp. 849-855. Sydney, Australia.

Anderson, R., Rayhani, M.T., Rowe, R.K., 2012. Laboratory investigation of GCL hydration from clayey sand subsoil. Geotext. Geomembr. 31, 31-38.

Azad, F., Rowe, R.K., El-Zein, A., Airey, D., 2011. Laboratory investigation of thermally induced desiccation of GCLs in double composite liner systems. Geotext. Geomembr. 29 (6), 534-543.

Azad, F., El-Zein, A., Rowe, R.K., Airey, D., 2012. Modeling of thermally induced desiccation of geosynthetic clay liners in double composite liner systems. Geotext. Geomembr. 34, 28

Barry-Macaulay, D., Bouazza, A., Singh, R.M., Wang, B., Ranjith, P.G., 2013. Thermal conductivity of soils and rocks from the Melbourne (Australia) region. Eng. Geol. 164, 131-138.

Beddoe, R.A., Take, W.A., Rowe, R.K., 2011. Water retention behaviour of GCLs J. Geotech. Geoenviron. Eng. 137 (11), 1028-1038.

Börgesson, L., Hernelind, J., 1998. Preparatory Modelling for the Backfill and Plug Test - Scoping Calculations of H-M Processes. SKB. IPR-99-11.

Bouazza, A., 2002. Geosynthetic clay liners. Geotext. Geomembr. 20 (1), 1-17.

Bouazza, A., 2010. Geosynthetics in mining applications. In: Proceedings 6th International Congress on Environmental Geotechnics, vol. 1, pp. 221-259. New Delhi, India.

Bouazza, A., Vangpaisal, T., 2003. An apparatus to measure gas permeability of geosynthetic clay liners. Geotext. Geomembr. 21 (2), 85-101.

Bouazza, A., Bowders, J.J., 2010. Geosynthetic Clay Liners for Waste Containment Facilities. CRC Press, 254 pp.

Bouazza, A., Gates, W.P., 2014. Overview of performance compatibility issues of GCLs with respect to leachates of extreme chemistry. Geosynth. Int. 21 (2), $151-167$.

Bouazza, A., Zornberg, J., Adam, D., 2002. Geosynthetics in waste containments: recent advances. In: Proceedings 7th International Conference on Geosynthetics, vol. 2, pp. 445-507. Nice, France.

Bouazza, A., Nahlawi, H., Alyward, M., 2011. In-situ temperature monitoring in an organic waste landfill cell. J. Geotech. Geoenviron. Eng. 137 (12), 1286-1289. 
Bouazza, A., Zornberg, J., McCartney, J., Singh, R.M., 2013. Unsaturated geotechnics applied to geoenvironmental engineering problems involving geosynthetics. Eng. Geol. 165, 143-153.

Chappel, M.J., Brachman, R.W.I., Take, W.A., Rowe, R.K., 2012a. Large-scale quantification of wrinkles in a smooth black HDPE geomembrane. J. Geotech. Geoenviron. Eng. 138 (6), 671-679.

Chappel, M.J., Rowe, R.K., Brachman, R.W.I., Take, W.A., 2012b. A comparison of geomembrane wrinkles for nine field cases. Geosynth. Int. 19 (6), 453-469.

Cleall, P.J., Singh, R.M., Thomas, H.R., 2011. Non-isothermal moisture movement in unsaturated kaolin: an experimental and theoretical investigation. ASTM Geotech. Test. J. 34 (5), 514-524.

Cleall, P.J., Singh, R.M., Thomas, H.R., 2013. Vapour transfer in unsaturated compacted bentonite. Geotechnique 63 (11), 957-964.

Ewen, J., Thomas, H.R., 1989. Heating unsaturated medium sand. Geotechnique 39 (3), 455-470.

El-Zein, A., Ghavam-Nasiri, A., Bouazza, A., Rowe, R.K., 2014. Performance of GCLs in brine ponds for coal-seam gas extraction sites: a theoretical investigation. In: Proceedings 7th International Congress on Environmental Geotechnics. Melbourne, November 2014 (in press).

Fourie, A.B., Bouazza, A., Lupo, J.F., Abrao, P., 2010. Improving the performance of mining infrastructure through the judicious use of geosynthetics. In: Proceedings 9th International Conference on Geosynthetics, vol. 1, pp. 193-219. Guaruja, Brazil.

Fourier, J., 1822. Théorie analytique de la chaleur. Firmin Didot, Paris.

Gates, W.P., Bouazza, A., 2010. Bentonite transformations in strongly alkaline solutions. Geotext. Geomembr. 28 (2), 219-225.

Gates, W.P., Bouazza, A., Churchman, J.G., 2009. Bentonite clay keeps pollutants at bay. Elements 5 (2), 105-110.

Hoor, A., Rowe, R.K., 2013. Potential for desiccation of geosynthetic clay liners used in barrier systems. ASCE J. Geotech. Geoenviron. Eng. 139 (10), 1648-1664.

Hornsey, W.P., Scheirs, J., Gates, W.P., Bouazza, A., 2010. The impact of mining solutions/liquors on geosynthetics. Geotext. Geomembr. 28 (2), 191-198.

Johansen, O., 1975. Thermal Conductivity of Soils (Ph.D. thesis). University of Trondheim, Norway.

Koerner, G.R., Koerner, R.M., 2006. Long term temperature monitoring of geomembranes at dry and wet landfills. Geotext. Geomembr. 24 (1), 72-77.

Liu, Y., Gates, W.P., Bouazza, A., 2013. Acid induced degradation of the bentonite component used in geosynthetic clay liners. Geotext. Geomembr. 36, 71-80.

Liu, Y., Gates, W.P., Bouazza, A., Rowe, R.K., 2014. Fluid loss as a quick method to evaluate the hydraulic conductivity of geosynthetic clay liners under acidic conditions. Can. Geotech. J. 51 (2), 158-163.

Lu, H., Walton, J.C., Swifte, A.H.P., 2001. Desalination coupled with salinity-gradient solar ponds. Desalination 136, 13-23.

Mazzieri, F., Di Emidio, G., Fratalocchi, E., Di Sante, M., Pasqualini, E., 2013. Permeation of two GCLs with an acidic metal-rich synthetic leachate. Geotext. Geomembr. 40, 1-11.

Melhuish, T.A., 2004. An Investigation of the Three-Dimensional Thermo/Hydro/ Mechanical Behaviour of Large Scale In-situ Experiments (Ph.D. thesis). Schoo of Engineering, University of Wales, Cardiff.

Mitchell, J.K., 1991. Conduction phenomena: from theory to geotechnical practice Geotechnique 41 (3), 299-340.

Mitchell, J.K., 1993. Fundamental of Soil Behaviour. John Wiley \& Sons, Inc., New York.

Philip, J.R., de Vries, D.A., 1957. Moisture movement in porous materials under temperature gradients. Trans. Am, Geophys, Union 38, 222-232.

Rayhani, M.T., Rowe, R.K., Brachman, R.W.I., Take, W.A., Siemens, G., 2011. Factors affecting GCL hydration under isothermal conditions. Geotext. Geomembr. 29 (6), 525-533.

Rowe, R.K., 2005. Long-term performance of contaminant barrier systems. Geotechnique 55 (9), 631-678.
Rowe, R.K., 2012. Short and long-term leakage through composite liners. The 7th Arthur Casagrande lecture. Can. Geotech. J. 49 (2), 141-169.

Rowe, R.K., Verge, A.E., 2013. Prediction of geosynthetic clay liner desiccation in low stress applications. Geosynth. Int. 20 (5), 301-315.

Rowe, R.K., Yang, P., Chappel, M.J., Brachman, R.W.I., Take, W.A., 2012a. Wrinkling of a geomembrane on a compacted clay liner on a slope. Geotech. Eng. J. South East Asian Geotech. Soc. 43 (3), 11-18.

Rowe, R.K., Chappel, M.J., Brachman, R.W.I., Take, W.A., 2012b. Field monitoring of geomembrane wrinkles at a composite liner test site. Can. Geotech. J. 49 (10), 1196-1211.

Rowe, R.K., Quigley, R.M., Brachman, R.W.I., Booker, J.R., 2004. Barrier Systems for Waste Disposal Facilities. Taylor\& Francis (E \& FN Spon), London.

Seetharam, S.C., 2003. An Investigation of the Thermo/Hydro/Chemical/Mechanical Behaviour of Unsaturated Soils (PhD thesis). Cardiff School of Engineering, University of Cardiff, UK.

Shackelford, C.D., Sevick, G.W., Eykholt, G.R., 2010. Hydraulic conductivity of geosynthetic clay liners to tailings impoundment solutions. Geotext. Geomembr. 28 (2), 149-162.

Silva, G., Almanza, R., 2009. Use of clays as liners in solar ponds. Sol. Energy 83 (6), 905-919.

Singh, R.M., Bouazza, A., 2013. Thermal conductivity of geosynthetics. Geotext. Geomembr. 39, 1-8.

Southen, J.M., Rowe, R.K., 2005. Laboratory investigation of GCL desiccation in a composite liner subjected to thermal gradients. J. Geotech. Geoenviron. Eng. 131 (7), 925-935.

Southen, J.M., Rowe, R.K., 2011. Numerical modelling of thermally induced desiccation of geosynthetic clay liners observed in laboratory experiments. Geosynth. Int. 18 (5), 289-303.

Smith, S.E., 2008. Emerging issues in heap leaching technology. In: Proceedings 4th European Conference on Geosynthetics. Edinburgh, CD-Rom.

Take, W.A., Chappel, M.J., Brachman, R.W.I., Rowe, R.K., 2007. Quantifying geomembrane wrinkles using aerial photography and digital image processing. Geosynth. Int. 14 (4), 219-227.

Thiel, R., Smith, M.E., 2004. State of the practice review of heap leach design issues. Geotext. Geomembr. 22, 555-568.

Thomas, H.R., Cleall, P.J., 1999. Inclusion of expansive clay behaviour in coupled thermo hydraulic mechanical models. Eng. Geol. 54, 93-108.

Thomas, H.R., He, Y., 1995. Analysis of coupled heat, moisture and air transfer in a deformable unsaturated soil. Geotechnique 45 (4), 677-689.

Thomas, H.R., He, Y., Sansom, M.R., Li, C.L.W., 1996. On the development of a model of the thermo-mechanical-hydraulic behaviour of unsaturated soils. Eng. Geol. 41, 197-218.

Thomas, H.R., He, Y., 1997. A coupled heat moisture transfer theory for deformable unsaturated soil and its algorithmic implementation. Int. J. Num. Meth. Eng. 40 (18), 3421-3441.

Thomas, H.R., King, S.D., 1991. Coupled temperature/capillary potential variations in unsaturated soil. J. Eng. Mech. 117 (11), 2475-2491.

Thomas, H.R., Li, C.L.W., 1997. An assessment of a model of heat and moisture transfer in unsaturated soil. Geotechnique 47 (1), 113-131.

Thomas, H.R., Sansom, M.R., 1995. Fully coupled analysis of heat, moisture and air transfer in unsaturated soil. J. Eng. Mech. 121 (3), 392-405.

van Genuchten, M.Th., 1980. A closed-form equation for predicting the hydraulic conductivity of unsaturated soils. Soil Sci. Soc. Proc. 44, 892-898.

Wang, J., 2000. Transient and Dynamic Thermo/Hydraulic/Mechanical Behaviour of Partially Saturated Soil (PhD thesis). Cardiff School of Engineering, University of Cardiff, UK.

Yesiller, N., Hanson, J.L., Liu, W.L., 2005. Heat generation in municipal solid waste landfills. J. Geotech. Geoenviron. Eng. 131 (11), 1330-1344. 